\title{
The effects of oviposition site on the development of the wood borer Coraebus florentinus (Coleoptera: Buprestidae)
}

\author{
ANA M. CÁRDENAS and Patricia GALLARDO
}

\begin{abstract}
Department of Zoology, Campus Rabanales, E-14071 University of Córdoba, Spain; e-mails: ba1cataa@uco.es; b42gatop@uco.es
\end{abstract}
Key words. Buprestidae, Coraebus florentinus, Jewel beetle, development, oviposition, Quercus, temperature

\begin{abstract}
Coraebus florentinus (Herbst) is one of the most important wood borer pests of oaks in forest ecosystems in the Mediterranean Region. It is considered to be a heliophilous species as it prefers the sunniest parts of the canopy of isolated trees. The biological significance of this preference is still unknown. Recently, the effect of temperature on the preimaginal development of this insect was established: high temperatures increase its probability of survival and shorten its developmental time. Continuing this line of research, this study was designed to determine whether C. florentinus exhibits selective oviposition behaviour and how variation in temperature due to differences in the position of the branches in which the larvae develop could affect the subsequent development of this species. To determine whether this insect selects the branches in which to lay its eggs, location data (north, south, upper half and lower half of the tops of the trees) for 112 damaged branches were analysed. The results confirm that females of $C$. florentinus do not lay their eggs at random at the tops of trees but rather choose branches that are exposed to the sun. To determine the effects of larval rearing temperature on the later development stages, an experiment consisting of five treatments was performed. Four of these treatments, each containing 25 infested branches derived from different orientations and positions in a tree (upper half of tree and north facing, upper half and south facing, lower half and north facing and lower half and south facing) were kept in culture chambers maintained at optimal conditions for pupal development $\left(28 \pm 2{ }^{\circ} \mathrm{C}\right.$ and $60-65 \%$ relative humidity). The fifth treatment with 25 branches infested collected from the most sun-exposed locations were kept in outdoor conditions. The results indicate that variation in temperature during larval development due to differences in branch location does not significantly affect survival, duration of developmental of pupae, emergence success or sex ratio of the adults.
\end{abstract}

\section{INTRODUCTION}

Coraebus florentinus (Herbst, 1801) is a xylophagous beetle of the Buprestidae Family, which attacks and damages mainly different species of Quercus (Schaefer, 1949; Zochi, 1953; Goidanich, 1954; Soria, 1990; Cárdenas \& Gallardo, 2012). Because of its particular affinity for the holm (Q. ilex Linné) and cork (Q. suber Linné) oaks this insect is mainly distributed in those areas of the Mediterranean Region where these oaks predominate.

Damage caused by $C$. florentinus is due to the feeding activity of larvae, which bore longitudinal and annular galleries under the bark of terminal branches that interrupt the sap flow and cause the death of branches in which this insect completes its development.

This reduction in the number of branches results in a progressive decay and loss of vigour (Jurc et al., 2009). The symptoms of the damage are easily identifiable and are widely described in the literature (Bachiller et al., 1981; Montoya, 1988; Soria \& Ocete, 1993; Cárdenas \& Gallardo, 2012).

The abundance of this insect is greatest in several countries in the Mediterranean basin (Italy, Spain and Portugal; Jurc et al., 2009), where the level of damage has considerably increased recently. This is because of the progressive abandonment of pruning before the emergence of the imago (Lombardero \& Fernández de Ana Magán, 1996), although this is considered the most effective method of control (Evans et al., 2004).
Adults of $C$. florentinus emerge for a very short period of time (June and July; Jurc et al., 2009) and although they feed on the leaves of their host plants, the defoliation they cause is not significant. This jewel beetle is most active during the hottest hours of the day and, preferably, on distal branches, which are most exposed to the sun. The female lays eggs (usually one per branch) in July and early August and after about two weeks they hatch and the larvae bore into the branch. Here, they feed and pierce host tissue over a period of two years (Goidanich, 1954; Ceballos, 1974; Solinas, 1974; Bachiller et al., 1981), although some references indicate that the larval phase can last up to three or four years (Cecconi, 1924; Fernández de Cordova \& Cabezuelo, 1995). As the species is markedly thermophilous (Cobos, 1986; Verdugo, 2005), it shows a preference for isolated trees and for south facing branches, which consequently are the most likely to be attacked by larvae (Ferreira \& Ferreira, 1991; Soria \& Ocete, 1993; Soria et al., 1996; Rivas, 2000).

In addition, it is widely accepted that temperature is the environmental factor that most affects insects' physiology (Faroni \& García-Mari, 1992; Dajoz, 2001; Bale et al., 2002) because it has a marked affect on their reproduction, population density and duration of their life cycle (Margaix \& Garrido, 2000). The influence of this factor on the preimaginal development of $C$. florentinus was recently demonstrated by Cárdenas \& Gallardo (2012), who found that with increase in temperature the probability of survival increases and the developmental time 
of this species decreases. Considering these results together with the information available in the literature, it is likely that the success of larval development is also influenced by temperature. Because the larvae of $C$. florentinus are endophytic organisms, the temperature during their development is mainly determined by that of their immediate environment, which is mainly dependent on the location of the branch in which they are developing. Thus, it is likely that the branches in the more sunny positions provide warmer and most favourable habitats for this insect's development.

In this respect, it is known that exposure to sun is an important abiotic factor in the oviposition behaviour of some thermophilic species of the Buprestidae Family (Garrido et al., 1987; Malagón et al., 1988).

Currently, there are several ongoing studies assessing the effect of temperature on the developmental stages of species of Buprestidae other than C. florentinus. In particular, Sobek et al. (2011) report the response of the immature developmental stages of Agrilus planipennis (Fairmaire) to different heating schedules, with the aim of developing an effective method to control this pest.

There are similar studies on the control of other woodboring beetles, such as Cerambycidae (Ostaff \& Cech, 1978; Mushrow et al., 2004), Platipodinae, Scolytidae, Bostrichidae (Snyder \& St. George, 1924; Ostaff \& Shields, 1978) and other xylophagous insects (Dwinell, 1990; Smith, 1991; Tomminen \& Nuorteva, 1992).

Most studies on heat tolerance only investigate its effect on emergence and short-term survival, but do not analyse the consequences of high temperature on longevity or fecundity of the imagoes.

Recent research has shown that for some species of Buprestidae (A. planipennis, Myers et al., 2009), Bostrichidae (Bains, 1971; Faroni \& García-Mari, 1992) and other phytophagous insects such as some Hymenoptera (Scott et al., 1997), Diptera (Huang et al., 2007) and Lepidoptera (Mironidis \& Savopoulou-Soultani, 2010), increasing temperature not only leads to shorter developmental times and higher percentage survival but also results in a reduction in the longevity and fecundity of the imagoes.

As for C. florentinus, previous studies (Cárdenas \& Gallardo, 2012) only consider the influence of temperature on pupal development and not on the previous immature stages. To complement these results, the present research was conducted with three clear objectives:

- To verify if $C$. florentinus females selectively oviposit in the warmer zones of trees.

- To determine how variation in temperature due to differences in the location of the branches in which the larvae develop affects the development of the insect.

- To assess the effect of temperature on the sex ratio of newly emerged adults, their longevity and the fecundity of the females.

This work is part of a research Project entitled "Study and Monitoring Plan of Wood-Boring beetles from Quercus species" included in the Compensatory Measures Program linked to the construction of the Breña II dam, which is located close to the Sierra de Hornachuelos Natural Park (92/43/EEC Habitat Directive of the European Council for the conservation of natural habitats and wildlife).

\section{MATERIAL AND METHODS}

\section{The area}

This research was carried out in a zone belonging to the Hornachuelos Natural Park (southern Iberian Peninsula), where damage caused by $C$. florentinus is known to occur (Gallardo, 2011). This is a natural area of considerable ecological value, composed of a typically mixed Mediterranean forest, where $Q$. ilex and $Q$. suber predominate. Currently, the area is being subjected to a Recovery Management Program linked to the construction of the Breña II dam, which is located close to the Park.

\section{Field work}

Between 2007 and 2008, a total of 1361 holm oaks were inspected for damage caused by $C$. florentinus. The damaged branches were identified by visually searching the tops of trees and locating terminal branches showing clear symptoms of damage by this species. All infested branches found during the inspection of the trees were considered to be part of this research.

The study of oviposition site selection was based on the fact that each damaged branch indicates the presence of a developing pupa of $C$. florentinus and, thus, a site where a female of this species laid an egg.

To determine whether this insect randomly oviposits or if, on the contrary, it selects branches on which to lay its eggs, location data (north, south, upper half and lower half of the top of a tree) for a total of 112 damaged branches were analyzed.

That the temperatures in different parts of a tree varied was verified by recording temperature in the upper- and lowerhalves and north and south orientations of the canopies of a total of 10 isolated holm-oaks, randomly selected in the study area. Temperatures were recorded daily, once every hour while the sun was shining ( 7 am to $10 \mathrm{pm}$ ), during the two first weeks of July, when C. florentinus is ovipositing (Jurc et al., 2009). The average values were statistically compared in order to determine whether the temperatures in the north and south facing, and upper- and lower-halves of the canopy differed significantly (data are given in appendix 1).

To study the effect of temperature on the postlarval development of $C$. florentinus, which depends on the location of the oviposition branch, an experiment was carried out in 2011. It consisted of five treatments, each containing 25 damaged branches collected from different sides and levels in the tops of trees: upper half and north facing, upper half and south facing, lower half and north facing and lower half and south facing. The east and west facing sides were not sampled because the differences in the temperatures recorded there are not as marked as on the north-south facing sides. All of the branches were from holm oaks and showed clear indications of infestation with C. florentinus. Detailed descriptions of these symptoms can be found in Romanyk \& Cadahia (1992). The branches were collected between the $1^{\text {st }}$ and $4^{\text {th }}$ of April 2011, immediately after pupation had started, which coincides with the appearance of the first symptoms of damage to the branches (Jurc et al., 2009; Cárdenas \& Gallardo, 2012).

For the identification and collection of the damaged branches, the same procedure was followed as described previously (Cárdenas \& Gallardo, 2012), which consisted of visually searching the tops of holm oaks and locating the affected branches. 
Once collected, the branches were pruned approximately 20 $\mathrm{cm}$ below the thickening that is produced by the pupation chamber, as described by Rodrigo \& Herranz (2006).

To reduce the effect that differences between trees may have on the results, only one branch was collected from each holm oak. The branches were collected from trees of middle age (between 65 and 100 years old). Tree age was estimated by measuring the diameters of the trunks at breast height (average $=35.27 \mathrm{~cm} \pm 8.33 \mathrm{SD}$ ) and applying the expression proposed by Plieninger et al. (2003) for holm oaks. The average distance between trees was estimated using the closest individual method (Henderson, 2003), which indicated an average density of 61 trees/Ha.

For each branch collected, the following parameters were recorded: UTM coordinates, basal diameter (just below the pupation chamber), length, date of collection and location (upper or lower) and orientation (north or south facing) in the top of the trees.

The length and diameter of the branches were highly variable, with average values of $134.92 \mathrm{~cm} \pm 28.01 \mathrm{SD}$ and $3.37 \mathrm{~cm} \pm 0.6$ $\mathrm{SD}$, respectively.

\section{Laboratory work}

In the laboratory, the branches were kept in bags of plastic breathable mesh, tightly sealed, labelled and distributed into five experimental groups of 25 branches each according to their orientation and position on the original tree. Four of these groups were placed in a growth chamber: treatment $\mathrm{T} 1$ (with branches from the upper half and north facing side of the canopies); treatment T2 (branches from the upper half and south facing side), treatment T3 (branches from the lower half and north facing side); and treatment T4 (branches from the lower half and south facing side). The fifth group (treatment T5), with branches from the upper half and south facing side of trees, was kept in outdoor conditions.

Because the last larval stage of $C$. florentinus interrupts the flow of sap and thus causes the branches to dry out, the use of pruned branches in the treatments is unlikely to affect the results. Likewise, branch moisture should not be a factor affecting the survival of the pupae or the adults.

The temperature in the growth chamber was $28 \pm 2^{\circ} \mathrm{C}$, which is optimal for the pupal development of this species (Cárdenas $\&$ Gallardo, 2012). The relative humidity in the culture chamber ranged between $60-65 \%$, which is similar to the average humidity in the study area during the period of April to July (http://www.juntadeandalucia.es/agriculturaypesca/ifapa). The endophytic life of the immature stages of this insect indicates that their development is not affected by the light cycle; thus, these four treatments were kept in constant darkness.

The fifth treatment (T5) consisted of branches from the most sun-exposed locations because according to previous results, the warmest conditions must be the most favourable for the development of the immature stages of this species. This treatment was kept outside, under natural conditions (natural light cycle, average temperature $=22.8 \pm 4.39^{\circ} \mathrm{C}$; average maximum temperature $=29.99 \pm 5.4^{\circ} \mathrm{C}$; average minimum temperature $=$ $15.60 \pm 3.29^{\circ} \mathrm{C}$ and average relative humidity $=64.3 \pm 20.5 \%$ ). Temperature and humidity were recorded with a portable thermo-hygrometer.

All of the branches were inspected every two days to record the time and the number of imagoes that emerged. The experiment was carried out between April and July, which is the period when $C$. florentinus emerges in the field (Jurc et al., 2009).

The experiment lasted from April 4 to July 15. At the end of this study, branches from which no adults emerged were exam- ined to confirm that the branch had originally dried out because of the action of the insect and to determine at which stage its development ceased. According to Stehr (1983) and Gullan \& Cranston (1998), the following stages were differentiated: larva, prepupa or pharate pupa, pupa or pharate adult, dead imago and viable imago. Full descriptions of each stage can be found in Cárdenas \& Gallardo (2012).

As the adults were obtained from each treatment, they were marked, sexed and placed in their respective insectaries. For recognition, insects were marked on the elytra by applying a dot of paint (Wineriter \& Walker, 1984) using Tech-Pen ink. Likewise, adult insects were sexed by observing their antenna, which differ in morphology in males and females (Verdugo, 2005).

The insectaries consisted of wooden boxes $35 \mathrm{~cm}$ wide, $37 \mathrm{~cm}$ high and $35 \mathrm{~cm}$ deep each fitted with two breathable grids, 24 $\mathrm{cm}$ wide and $26 \mathrm{~cm}$ high, which were kept the conditions in the insectaries close to ambient. Each insectary was supplied with small pieces of apical branches (approximately $60 \mathrm{~cm}$ in length and $1 \mathrm{~cm}$ in diameter) of holm oak, whose leaves served as food for adults and bark provided a suitable substrate for the females to lay eggs. The branches were replaced every two days and carefully scanned for the presence of eggs.

To check for differences in the reproductive status of the females emerging from branches in each treatment, the anatomy of their gonads was recorded. All the females from the different treatments (a total of 29) were dissected in order to determine the state of maturation of their ovarioles. Following Cárdenas (1994) and Cárdenas \& Hidalgo (2000), after removing the ovaries and examining the ovarioles, the females were assigned to one of the following stages:

- Immature, if the ovarioles were not differentiated.

- Reproductive if oocytes were clearly visible, but there were no mature ova or corpora lutea.

- Gravid females if there were mature ova but no corpora lutea.

\section{Data analysis}

To determine whether the branches damaged by C. florentinus are distributed randomly or mainly in the tops of trees, the data on the location of damaged branches were analyzed using Chi-squared tests. The same procedure was used to test differences in the number of larvae, prepupae, pupae and viable imagoes that emerged from branches kept in the different treatments (T1, T2, T3 and T4) and to assess the reproductive condition of the females dissected. To test differences in the number of larvae, prepupae, pupae and viable imagoes obtained from T2 and T5 treatments, a binomial distribution test was performed. This analysis was also used to determine differences in the sex ratio of the imagoes emerging from different treatments.

For each treatment, the number of individuals corresponding to each developmental stage was quantified and the average duration of the pupal stage was recorded. The percentage emergence was defined as the percentage of specimens that reached the adult stage (dead or alive), and the percentage survival as the percentage of living imagoes recorded in each treatment.

The nonparametric Kruskal Wallis test was used to assess the differences among the treatments when the adults emerged from the branches. To compare the survival time of the imagoes that emerged in each treatment, an analysis of variance (ANOVA) was applied to the data set. The assumptions of normality and homoscedasticity were previously verified by the Shapiro-Wilk and Levene tests (Zar, 1984). All statistical tests were conducted with $\alpha=0.05$. Calculations were performed using SP statistical software (SPSS 20.0, 2011). 
TABLE 1. Number of branches infested with Coraebus florentinus on the north and south facing sides and in the upper and lower canopy of holm oak trees.

\begin{tabular}{lccc}
\hline \multirow{2}{*}{ Position } & \multicolumn{3}{c}{ Side of tree } \\
\cline { 2 - 4 } & North & South & Total \\
\hline Upper canopy & 30 & 32 & 62 \\
Lower canopy & 16 & 34 & 50 \\
Total & 46 & 66 & 112 \\
\hline
\end{tabular}

\section{RESULTS}

\section{Analysis of the oviposition site of $\boldsymbol{C}$. florentinus}

By analysing the distribution of damaged branches in the tops of the trees, it is possible to determine whether oviposition was random or whether the insect carefully selected where to oviposit. The 112 branches observed in the field showing clear symptoms of damage by $C$. florentinus were pooled according to their position (upper or lower half) and orientation (north or south facing) in the tops of the trees (Table 1).

The most remarkable result is the low number of branches from the north facing and lower halves of the trees colonised by this insect (16) compared to the numbers of branches in the other positions, which were evenly represented and for which there was almost double the number of branches. Nevertheless, the analysis of these data did not indicate a significant difference between the numbers of damaged branches in the different locations in the canopy: $\chi^{2}$ (Chi-squared) $=7.14, \mathrm{P}$ (Probability) $=$ 0.06 , D.F. (Degrees of freedom) $=3$.

If the numbers in upper and lower positions are pooled, then the Chi-squared test indicates that there were significantly different numbers of damaged branches in the north and south facing parts of the canopy (Table 2). However, the most significant difference was in the higher percentage of damaged branches in the lower half of the south facing canopy (68\%) than in the lower half of

TABLE 2. Chi-squared statistics $\left(\chi^{2}\right)$ and probability $(\mathrm{P})$ values of the differences in the number of branches infested with Coraebus florentinus on the north and south sides and in the upper and lower canopies of holm oak trees. Degrees of freedom (D.F.) $=1$.

\begin{tabular}{|c|c|c|c|}
\hline \multirow{2}{*}{\multicolumn{2}{|c|}{$\begin{array}{l}\text { Location of the infested branches } \\
\text { in the canopies of the trees }\end{array}$}} & \multicolumn{2}{|c|}{ Chi-squared statistics } \\
\hline & & \multirow{2}{*}{$\begin{array}{c}\chi^{2} \\
0.06\end{array}$} & \multirow{2}{*}{$\begin{array}{c}\mathrm{P} \\
0.8\end{array}$} \\
\hline Upper canopy & $\begin{array}{l}\text { North side } \\
\text { South side }\end{array}$ & & \\
\hline Lower canopy & $\begin{array}{l}\text { North side } \\
\text { South side }\end{array}$ & 6.48 & 0.01 \\
\hline Both positions & $\begin{array}{l}\text { North side } \\
\text { South side }\end{array}$ & 3.57 & 0.05 \\
\hline North side & $\begin{array}{l}\text { Upper canopy } \\
\text { Lower canopy }\end{array}$ & 4.26 & 0.03 \\
\hline South side & $\begin{array}{l}\text { Upper canopy } \\
\text { Lower canopy }\end{array}$ & 0.06 & 0.8 \\
\hline $\begin{array}{c}\text { Both } \\
\text { orientations }\end{array}$ & $\begin{array}{l}\text { Upper canopy } \\
\text { Lower canopy }\end{array}$ & 1.29 & 0.26 \\
\hline
\end{tabular}

TABle 3. Number of Coraebus florentinus larvae, prepupae, pupae, dead imagoes, viable imagoes and sex ratio (number males/number females) recorded in each treatment (T). Percentage emergence: Percentage of specimens that reached the adult stage (dead or alive). Percentage survival: Percentage of living adults. T1, T2, T3 and T4: treatments carried out under controlled conditions in culture chambers and T5: treatment carried out under natural conditions. T1: branches from the upper half and northern side of canopies, T2: upper half and southern side, T3: lower half and northern side, T4: lower half and southern side, T5: upper half and southern side.

\begin{tabular}{lccccc}
\hline Treatments & T1 & T2 & T3 & T4 & T5 \\
\hline Number of larvae & 2 & 3 & 1 & 4 & 2 \\
Number of prepupae & 4 & 7 & 4 & 3 & 7 \\
Number of pupae & 5 & 3 & 6 & 5 & 8 \\
Number of dead imagoes & 0 & 1 & 1 & 1 & 0 \\
Number of viable imagoes & 14 & 11 & 13 & 12 & 8 \\
Sex ratio & 1 & 2.67 & 1.17 & 0.5 & 0.6 \\
Percentage emergence & 56 & 48 & 56 & 52 & 32 \\
Percentage survival & 56 & 44 & 52 & 48 & 32 \\
\hline
\end{tabular}

the north facing canopy (32\%). Similarly, the number of damaged branches in the north facing and upper parts of the canopy was significantly greater than in the north facing lower parts (Table 2).

\section{The effect of the location of branches on the development of $C$. florentinus}

Relationship between branch location and viability of the developmental stages

Data related to the development of $C$. florentinus in each treatment are recorded in Table 3. Based on these data, it can be stated that for T1, T2, T3 and T4 treatments, the location on a tree from which a branch was collected did not significantly affect the number of larvae, prepupae and pupae recorded: $\chi^{2}=2, \mathrm{P}=0.57$, D.F. $=3$; $\chi^{2}=2, \mathrm{P}=0.57$, D.F. $=3$ and $\chi^{2}=1, \mathrm{P}=0.8$, D.F. $=3$, respectively.

In these treatments close to $50 \%$ of the individuals died before reaching the adult stage, irrespective of the location on a tree from which the branch in which the larva developed was collected. The percentage survival in T1, T2, T3 and T4, accordingly, did not differ significantly $\left(\chi^{2}=0.4, \mathrm{P}=0.94\right.$, D.F. $\left.=3\right)$.

In $\mathrm{T} 5$, the percentage of pupae that ceased development before reaching the adult stage increased to $68 \%$. Nevertheless, when the number of larvae, prepupae, pupae and imagoes recorded in treatment (T5) are compared with those of T2, for which the damaged branches were collected from similar locations on the trees, south facing and upper position, the differences were not statistically significant for any of the developmental stages $(\mathrm{P}=1$, D.F. $=1$ for larvae; $\mathrm{P}=1, \mathrm{D} . \mathrm{F} .=1$ for prepupae; $\mathrm{P}=0.23$, $\mathrm{D} . \mathrm{F} .=1$ for pupae and $\mathrm{P}=0.65, \mathrm{D} . \mathrm{F}=1$ for imagoes).

Relationship between branch location and duration of the prepupal-adult phase

When the mean duration of the prepupal-adult phase in the different treatments (Table 3 ) is analysed, it is clear 


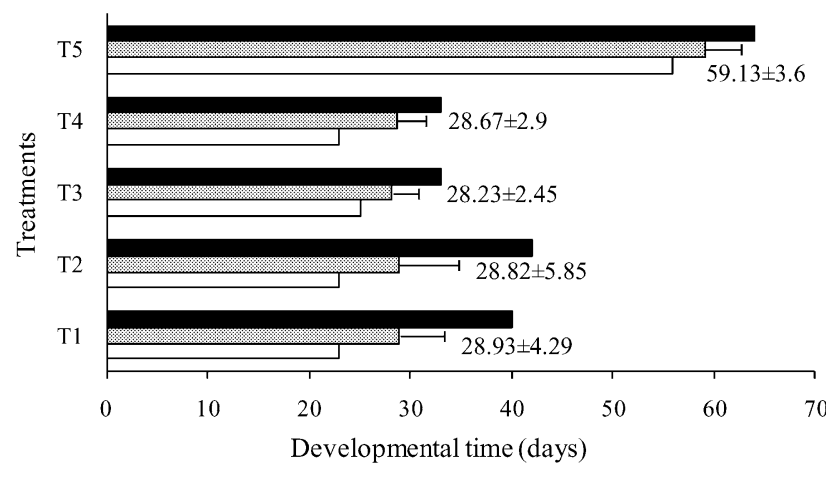

- Maximum time $\mathbb{0}$ Mean time $\square$ Minimum time

Fig. 1. The maximum, mean and minimum time (in days \pm S.D.) that Coraebus florentinus took to complete its development in the different treatments (T1, T2, T3 and T4 were carried out under controlled conditions in culture chambers and T5 under outdoor environmental conditions). Black bar: maximum value, grey bar: mean value and white bar: minimum value. T1: branches collected from the upper half on the north side of the canopies, T2: upper half on the south side, T3: lower half on the north side, T4: lower half on the south side, T5: upper half on the south side.

that under culture chamber conditions, the location from which the damaged branches were collected does not affect the duration of the pre-imaginal period. Indeed, the graphical representation of the duration (in days) of the prepupa-adult interval in the different treatments,

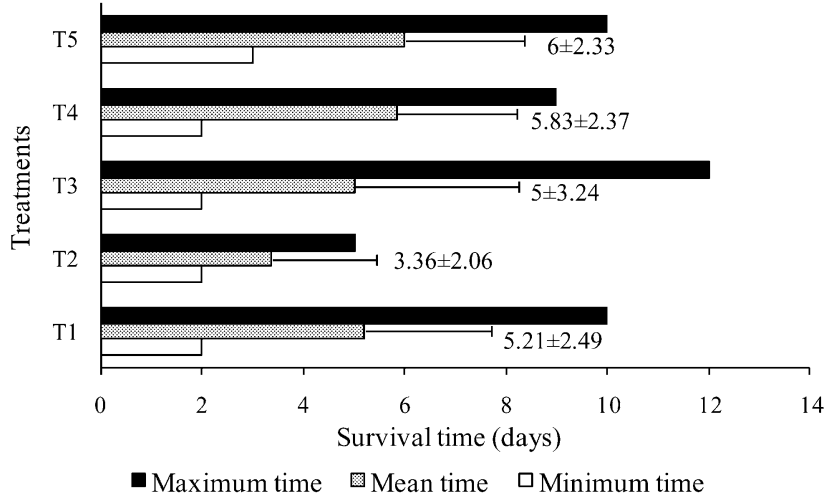

Fig. 2. The maximum, mean and minimum time (days \pm S.D.) for which the adults of Coraebus florentinus survived in the different treatments (T1, T2, T3 and T4 carried out under controlled conditions in culture chambers and $\mathrm{T} 5$ carried out under outdoor conditions). Black bar: maximum value, grey bar: mean value and white bar: minimum value. T1: branches collected from the upper and north facing side of the canopies, T2: upper half and south facing, T3: lower half and north facing, T4: lower half and south facing, T5: upper half and south facing.

including those reared under natural conditions (Fig. 1), suggests that the only difference is in T5. These differences have been statistically quantified and confirmed using the nonparametric Kruskal-Wallis test, which indicates highly significant differences: F (Statistical of test of significance $)=21.75, \mathrm{P}($ Probability $)=0$.
T1

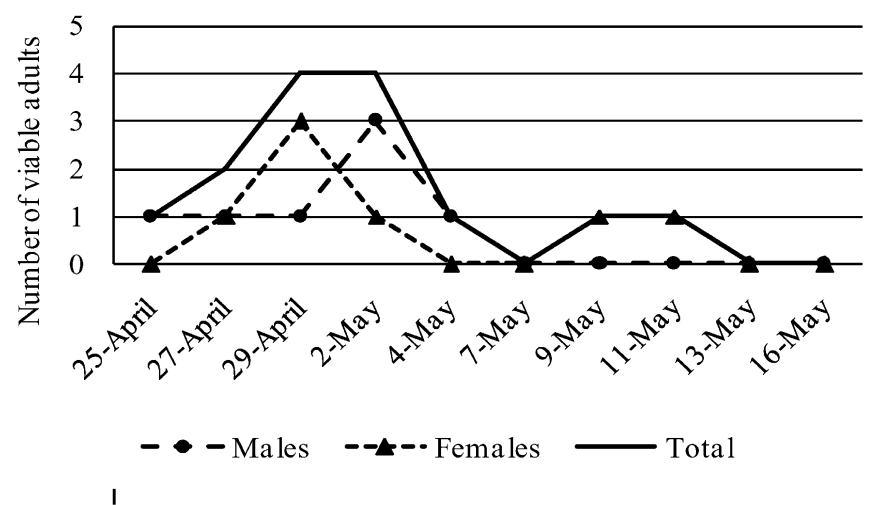

T3

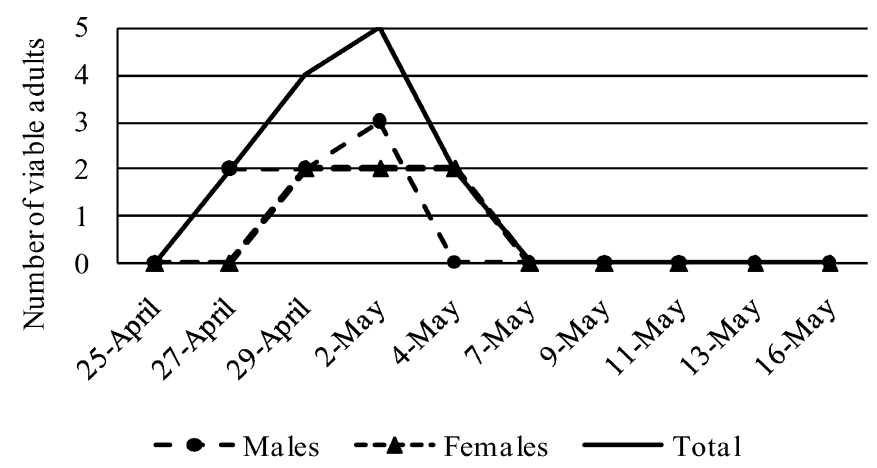

T2

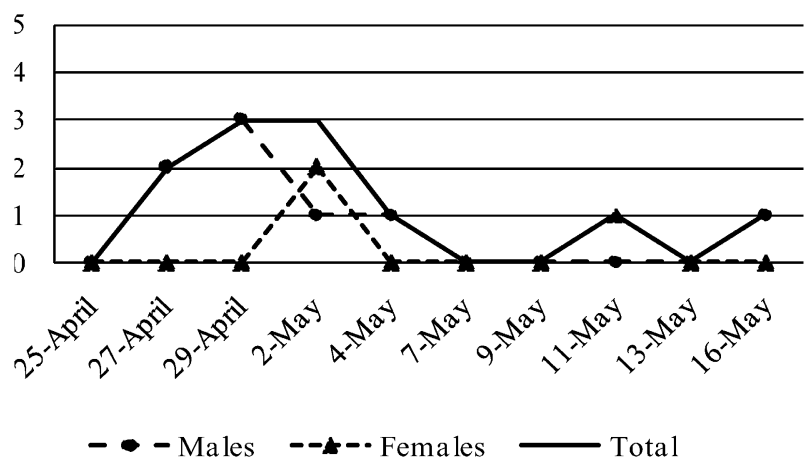

T4

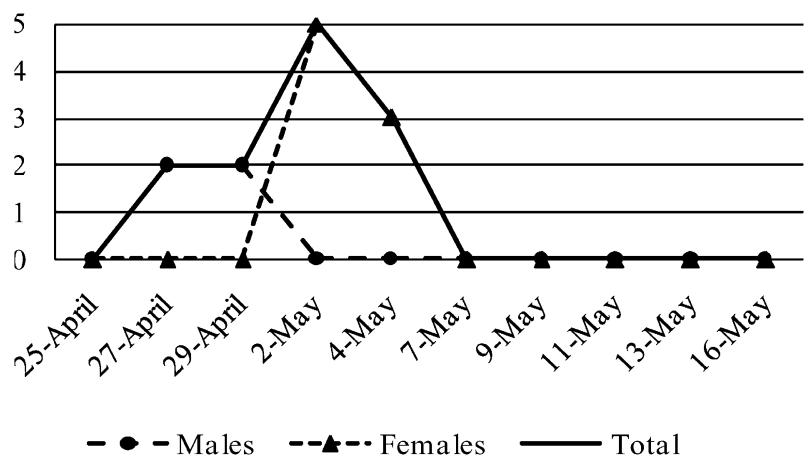

Fig. 3. Number of viable adults of Coraebus florentinus (males, females and total adults) recorded every two days that emerged in the treatments carried out under controlled conditions in the culture chamber. T1: branches collected from the upper half and north side of the canopies; T2: upper half and south side; T3: lower half and north side and T4: lower half and south side. 
T5

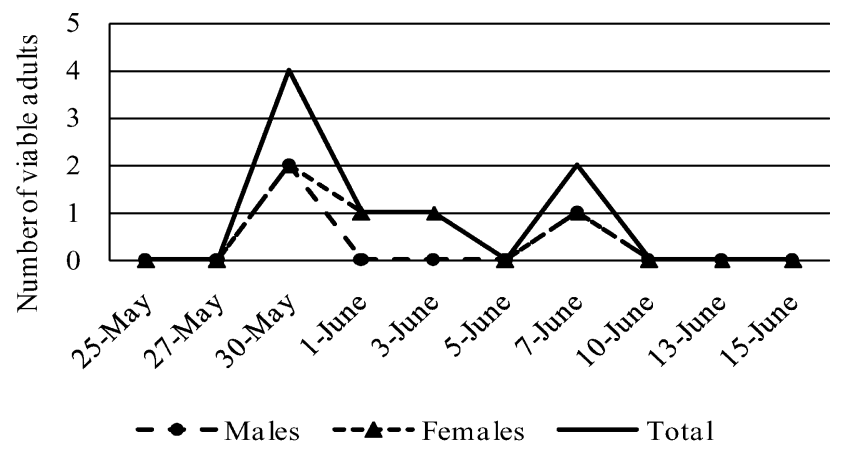

Fig. 4. Number of viable adults of Coraebus florentinus (males, females and total adults) recorded every two days that emerged in the treatment carried out under natural environmental conditions (T5). Branches in T5 were collected from upper half and south side of canopies.

Relationship between branch location and the time for which the imagoes survived

The maximum, mean and minimum values of the times for which the imagoes survived in each treatment are presented in Fig. 2. There does not appear to be any marked difference in the survival times of the adults that emerged in each treatment, including that kept in outdoor conditions (T5). This evaluation was statistically checked after performing an analysis of variance (ANOVA). The results indicate that neither the location of the branches in the canopy nor the conditions in which the branches were kept influenced the time for which the adults of $C$. florentinus survived $(\mathrm{F}=1.76, \mathrm{P}=0.15)$.

Relationship between branch location and the time of emergence

From the records of the dates on which the viable adults of $C$. florentinus emerged graphs of the numbers emerging over time in each treatment were plotted (Figs 3 and 4).

These graphs indicate that for those treatments kept in culture chamber conditions (T1, T2, T3, and T4) there were no noticeable differences in the number or the timing of the emergences: in the four treatments, viable adults started to emerge at the end of April, reaching a maximum in early May and ended two weeks later. Nevertheless, in the T5 treatment, the imagoes do not begin to emerge until late May, which extended the emergence period until the first week of June.

When the sex of the adults that emerged in each treatment is taken into consideration (Table 3) there was no lag in the time of emergence of males and females. In quantitative terms, the sex ratio appears to be balanced in most of the treatments.

This appraisal was checked after applying a binomial distribution test, which resulted in no significant differences for any of the cases considered (T1 $\Rightarrow \mathrm{P}=1 ; \mathrm{T} 2 \Rightarrow$ $\mathrm{P}=0.23 ; \mathrm{T} 3 \Rightarrow \mathrm{P}=1 ; \mathrm{T} 4 \Rightarrow \mathrm{P}=0.39$ and $\mathrm{T} 5 \Rightarrow \mathrm{P}=$ $0.73)$.
TABle 4. Percentages (\%) of immature and reproductive females in each treatment (T). T1, T2, T3 and T4 carried out under controlled conditions in culture chambers and T5 carried out under outdoor environmental conditions. T1: branches collected from the upper half of the north side of the canopies, T2: upper half of the south side, T3: lower half of the north side, T4: lower half of the south side, T5: upper half of the south side.

\begin{tabular}{lccccc}
\hline Treatments & T1 & T2 & T3 & T4 & T5 \\
\hline \% Immature females & 57.14 & 66.67 & 33.33 & 62.5 & 40 \\
\% Reproductive females & 42.86 & 33.33 & 66.66 & 37.5 & 60 \\
\hline
\end{tabular}

\section{Anatomical study of females}

To determine the reproductive state of females of $C$. florentinus that emerged in each of the different treatments they were dissected and their ovaries removed and studied. All the females studied, regardless of treatment, had developing gonads and were in breeding condition.

Approximately one-half of all of the females dissected (Table 4) did not start yet the reproduction (immature) because there had only undifferentiated ovarioles in their gonads; the remaining females had fully developed ovarioles with oocytes in different stages of maturation. None of the females were gravid.

The Chi-squared analysis of the data in Table $4\left(\chi^{2}=\right.$ $1.81, \mathrm{P}=0.77$, D.F. $=4$ ) indicates that the reproductive stage of the females does not significantly vary with the location of the branches where the larvae developed or with the rearing conditions during the preimaginal period.

All of the females died before they matured eggs and no eggs were found in any of the insectaries.

\section{DISCUSSION AND CONCLUSIONS}

C. florentinus is thought to be a heliophilous and thermophilous insect (Cobos, 1986; Soria, 1990; Verdugo, 2005) because field observations of adults and the damage caused by their larvae are mostly recorded in the sunniest parts of the canopies of oaks. However, the ethological aspects of sun-loving in this insect is unknown.

Recently, a study was conducted to determine the effect of temperature on the preimaginal development of $C$. florentinus (Cárdenas \& Gallardo, 2012), which found that with increase in temperature the duration of the pupal stage shortens and the percentage survival of adults increases. Continuing this line of research we checked whether C. florentinus is selective in where it lays its eggs and whether differences in temperature determined by the position of the branch in the canopy in which the larvae developed affected subsequent development (of either the pupa or adult).

The results confirm that females of $C$. florentinus do not lay eggs at random but prevent north facing branches located in the lower half of the top of a tree. The other locations considered appear to be equally suitable because their respective frequencies of occupation were similar.

The lack of an association with branches that receive less solar radiation must be related to the thermal requirements of this species, either in all or in some of its imma- 
ture stages. In similar studies in cork oak forests in the southern Iberian Peninsula (Soria \& Ocete, 1993), Coraebus behaves more selectively, mostly colonizing branches on the south and south-east facing sides of the canopy of the trees. This slight discrepancy may be because cork forests grow in more humid soils and shady environments, where sufficiently sun-exposed branches are only be found on the south facing side of the canopies of the trees.

The questions of how temperature affects oviposition and the embryonic development of $C$. florentinus were not addressed in this study. However, in other thermophilic species of jewel beetles there is a clear relationship between sun-exposure of the eggs and the percentage that hatch and the time they take to hatch. According to Balachowsky (1962) and Bonnemaison (1964), the flatheaded root-borer Capnodis tenebrionis Linné requires temperatures between 20 and $37^{\circ} \mathrm{C}$ for mating and laying eggs. In addition, Garrido et al. (1987) indicate that for egg-laying, females of $C$. tenebrionis should receive direct sunlight for from 6 to $10 \mathrm{~h}$. In relation to other species of wood boring beetles, Keena (2006) found that temperature not only affects the number of eggs laid by the female of Anoplophora glabripennis (Motschulsky) (Coleoptera: Cerambycidae) but also the percentage of eggs hatching.

This study on the effect of temperature on the development of immature stages of $C$. florentinus indicate that the location of the branches does not determine significant differences in the number of prepupae, pupae and adults but indicates as suggested by previous research that temperature is a more important factor during the prepupa and pupa than in the early stages of development. It is likely that this is so because larvae are well adapted to survive severe fluctuations in temperature that occur during the longest period of their life, the larval stages.

This type of larval adaptation can be explained in terms of the physiological mechanisms developed by the insect in response to the high summer temperatures. In this sense, studies on the thermal plasticity of insects (Thomas \& Shellie, 2000; Lurie \& Jang, 2007) attribute the ability to tolerate thermal fluctuations during the larval phases to the induction of heat shock proteins. Crosthwaite et al. (2011) and Sobek et al. (2011) report that in the emerald ash borer $A$. planipennis, the heat shock response results in an increase in thermo-tolerance after a short exposure to elevated temperatures and that this also provides protection against periods of cold and daily fluctuations in temperature. This type of tolerance is also found in leafbeetle species, such as the willow-beetle Chrysomela aeneicollis (Schaeffer) (Coleoptera: Chrysomelidae) (Neargarder et al., 2003; McMillan et al., 2005).

With respect to $C$. florentinus, it can be argued that larval development occurs over an extended period of time (from July to April of the next year), during which there are very striking oscillations in temperature, and that the time spent in prepupae and pupae is very short (from April to June) and at a time when environmental conditions are less extreme. Under these circumstances, larvae would benefit from acquired thermal resistance as it would protect them from the low winter temperatures and the hot summer temperatures that prevail in the southern part of the Iberian Peninsula.

Another factor that may be important is the temperature inside the branch. Because both larva and pupa of $C$. florentinus are endophytic, variations in temperature in the substrate in which they develop may determine their respective responses to temperature. In fact, larvae live in deeper inner galleries than pupae, where wood provides more insulation and protection against fluctuations in climate. Myers et al. (2009) monitored the temperature inside the wood of Fraxinus ssp., which is inhabited by the larvae and prepupae of the emerald ash borer A. plannipennis; they record that the pupae often reside just below the interface between the bark and the vascular cambium and that larvae could also survive in cold spots in the wood. Generally, regions deep in wood and external areas of higher relative density, such as knots and branch nodes, respond more slowly to environmental changes than less dense areas (Derby \& Gates, 1966; Simpson, 2001). The greater thermo-tolerance of the larval stages compared to that of the eggs, pupae and adults of boring beetles is described by Hansen \& Jensen (1996) in Anobium punctatum (De Geer) (Coleoptera: Anobiidae), Roonwal (1971) in Dinoderus ocellaris (Stephens) (Coleoptera: Bostrychidae), Mushrow et al. (2004) in Tetropium fuscum (Fabricius) (Coleoptera: Cerambycidae) and more recently by Keena \& Moore (2010) in $A$. glabripennis.

The temperature adaptation of the larvae of $C$. florentinus is also suggested by the lack of differences in the time taken to complete development of prepupae coming from larvae reared under different degrees of exposure to sun. Nevertheless, if the pupae experience warmer conditions, their time to emergence is significantly shorter (Cárdenas \& Gallardo, 2012).

The percentage survival of adults of $C$. florentinus was not related to the location of the branch in which the larvae developed. Thus, it is likely that the temperature at which the larvae are reared has no significant effect on adult viability. The percentage survival was approximately $50 \%$ in all the controlled treatments, which is in agreement with results previously obtained under similar conditions and also comparable to those of Soria (1990) recorded under laboratory conditions with average temperatures ranging between 25.5 and $27.9^{\circ} \mathrm{C}$. In the outdoor environmental conditions treatment, the percentage survival was significantly lower, not greater than $32 \%$, probably because the average temperature in spring 2011 was lower than normal $\left(22.8^{\circ} \mathrm{C}\right.$; http://www. juntadeandalucia.es/agriculturaypesca/ifapa).

The longevity of $C$. florentinus adults was not affected by the degree to which the branches were exposed to sun during larval development. Comparing our results with those of Soria (1990), in our study the temperatures were higher and the individuals lived for shorter periods and grew faster. That is, increased temperature accelerates the development of pupae but shortens the life of adults. 
Comparable conclusions were drawn by Nzokou et al. (2008) from tests conducted over different thermal ranges on other species of Buprestidae (A. planipennis). According to Slansky \& Scriber (1985), a higher temperature increases metabolism but reduces the life span proportionately for these species. This conclusion is also supported by studies on diverse phytophagous insects, which indicate that, in general, a rise in temperature increases abundance but, in turn, the adults are smaller (Bale et al., 2002) and have a reduced longevity (Keena, 2006), making their populations less stable (Zhou et al., 1997).

In some beetle species, temperature may also affect the population sex ratio. A slightly greater number of males than females of Rhyzopertha dominica (Fabricius) (Coleoptera: Bostrichidae) are recorded when the temperature at which the larvae are reared is high $\left(32-35^{\circ} \mathrm{C}\right)$, (Golebiowska, 1962; Faroni \& Garcia-Mari, 1992).

Nevertheless, in agreement with Soria (1990), we did not find any significant differences in the sex ratios of $C$. florentinus that emerged in the different treatments.

In terms of how the thermal regime experienced by the larvae affects the fertility of $C$. florentinus, no data are available because no females laid eggs before dying. However, research on other beetle species ( $R$. dominica) indicate that the highest fecundities are recorded at the higher temperatures (Golebiowska, 1962; Faroni \& Garcia-Mari, 1992). In addition, studies by Kenna (2006) and Kenna \& Moore (2010) on the wood borer, A. glabripennis, indicate that oviposition, fecundity and fertility increase when the temperature increases from 10 to $25^{\circ} \mathrm{C}$ and decrease again at higher temperatures.

Regarding the reason why $C$. florentinus did not complete its life cycle in any of the treatments, it can be argued that some woodboring beetles (A. glabripennis) need precopulatory and preovipositional periods in which the insects must encounter suitable conditions of temperature, humidity and diet (Keena, 2006). In the case of $C$. florentinus, the nature of these requirements is not known, but field precopulatory maturation, with feeding requirements in which the adults chew out of their hosts, may allow them to find different vegetal species necessary to complete the egg development or to maintain vigour in males. In support of this there are some records of adults of $C$. florentinus on flowers of herbaceous plants in meadows, such as Dittrichia viscosa (Linné) and daisies (Verdugo, 2005). We supplied soft leaves of holm oak as food because the bibliographic information on the food of this species (Soria, 1990) indicates that it prefers the leaves of the holm oak over those of rock roses. We verified that adults fed during the experiment, but all them died before reproduction. These unknown aspects of the biology of this pest will be addressed in future research aimed at improving management programs.

In conclusion, based on the current results and those of prior research, it can be stated that temperature is an important factor determining the rate of development of C. florentinus. It accounts for why females choose the most sun-exposed branches on which to lay eggs. In addi- tion, the effect of temperature on pupae is more marked than on the larval stages and that the difference in the position of the branches occupied by the larvae does not affect the developmental times of the latter stages, the percentage emergence or sex ratio of the adults.

ACKNOWLEDGEMENTS. We would like to thank ACUAVIR (Environmental Ministry, Government of Spain) for financially supporting this research.

\section{REFERENCES}

Bachiller P., Cadahia D., Ceballos G., Ceballos P., Cobos J.M., Cuevas P., Dafauce C., Davila J., González J.R., Hernández R., Ledesma L., Mallen J.A., Molina J., Montoya R., Neira M., Obama E., Riesgo A., Robredo F., Romanyk N., Rupérez A., SÁnchez A., Soria S., Toimil F.J. \& Torrent J.A. 1981: Plagas de Insectos en las masas forestales españolas. Ministerio de Agricultura, Pesca y Alimentación, Madrid, $254 \mathrm{pp}$.

BAINS S.S. 1971: Effect of temperature and moisture on the biology of Rhyzopertha dominica Fabricius (Bostrichidae: Coleoptera). - Bull. Grain Technol. 9: 257-264.

Balachowsky A.S. 1962: Entomologie Appliquée à l'Agriculture. Vol. 1. Coléoptères. Masson et Cie, Paris, 1634 pp.

Bale J.S., Masters G.J., Hodkinson I.D., Awmack C., Bezemer T.M., Brown V.K., Butterfield J., Buse A., Coulson J.C., Farrar J., Good J.E.G., Harrington R., Hartley S., Jones T.H., Lindroth R.L., Press M.C., Symrnioudis I., Watt A.D. \& WhitTAKer J.B. 2002: Herbivory in global climate change research: direct effects of rising temperature on insect herbivores. - Glob. Change Biol. 8: 1-16.

BonNEMAison L. 1964: Enemigos animales de las plantas cultivadas y forestales II. Coleópteros y Lepidópteros. Ediciones de Occidente, Barcelona, 496 pp.

CÁrdenas A.M. 1994: On the life history of Calathus granatensis (Coleoptera: Carabidae) in southwest Iberian Peninsula. In Desender K., Dufrêne M., Loseau M., Luff M.L. \& Maelfait J.P. (eds): Carabid Beetles. Ecology and Evolution. Kluwer, Dordrecht, pp. 109-115.

CÁrdenas A.M. \& Gallardo P. 2012: The effect of temperature on the preimaginal development of the Jewel beetle Coraebus florentinus (Coleoptera: Buprestidae). - Eur. J. Entomol. 109: $21-28$.

CÁrdenas A.M. \& Hidalgo J.M. 2000: Seasonal activity reproductive biology of the ground beetle Carabus dufouri (Coleoptera: Carabidae). - Eur. J. Entomol. 97: 329-338.

Ceballos G. 1974: Elementos de Entomología General. Escuela Técnica Superior de Ingenieros de Montes, Madrid, $330 \mathrm{pp}$.

Cecconi G. 1924: Manuale di Entomologia forestale. Tp. Seminario, Padova, 680 pp.

Совоs A. 1986: Fauna Ibérica de Coleópteros Bupréstidos. Consejo Superior de Investigaciones Científicas, Madrid, 364 pp.

Crosthwaite J.C., Sobek S., Lyons D.B., Bernards M.A. \& SinCLAIR B.J. 2011: The overwintering physiology of the emerald ash borer, Agrilus planipennis Fairmaire (Coleoptera: Buprestidae). - J. Insect Physiol. 57: 166-173.

DAJoz R. 2001: Entomología forestal: Los insectos y el bosque. Mundi-Prensa, Madrid, 548 pp.

Derby R.W. \& Gates D.M. 1966: The temperature of tree trunks-calculated and observed. - Am. J. Bot. 53: 580-587.

Dwinell D.L. 1990: Heat-treating and drying southern pine lumber infested with pinewood nematodes. - Forest Prod. $J$. 40: $53-56$. 
Evans H.F., Moraal L.G. \& Pajares J.A. 2004: Biology, ecology and economic importance of Buprestidae and Cerambycidae. In Lieutier F., Day R.K., Battisti A., Gregoire J.C. \& Evans F.H. (eds): Bark and Wood Boring Insects in Living Trees in Europe, a Synthesis. Kluwer, Dordrecht, pp. 447-474.

FARONI L.R.A. \& GARCÍA-MARI F. 1992: Influencia de la temperatura sobre los parámetros biológicos de Rhyzopertha dominica (F.). - Bol. San. Veg. Plagas 18: 455-467.

Fernández de Cordova J. \& Cabezuelo P. 1995: La "seca de ramillas" o "banderas" de la encina (Coroebus florentinus Herbst). Distribución biológica y lucha mecánica en la provincia de Córdoba. - Phytoma España 71: 31-37.

Ferreira M.C. \& Ferreira G.W.S. 1991: Pragas das folhosas. [Hardwood Pests.] Guia de campo. Serie divulgaçao No 5. Ministério da Agricultura, Pescas e Alimentaçao, Lisboa, 191 pp.

Gallardo P. 2011: Incidencia de coleópteros perforadores en formaciones de Quercineas del suroeste peninsular: Evaluación de daños y propuestas para la conservación. $\mathrm{PhD}$ Thesis, Universidad de Córdoba, 232 pp.

Garrido A., Del Busto T. \& Malagón J. 1987: Método de recogida de huevos de Capnodis tenebrionis L., (Col.: Buprestidae) y algunos factores abióticos que pueden condicionar la puesta. - Bol. San. Veg. Plagas 13: 303-309.

GoIdanich A. 1954: Enciclopedia Agraria Italiana, Vol. 2. Ramo Editoriale degli Agricoltori, Stabilimento Tipografico R.E.d.A., Roma.

GolebiowsKa Z. 1962: Contribution to studies on the ecology of the lesser grain borer Rhyzopertha dominica F. (Col., Bostrichidae). - Pol. Pis. Entomol. (B) 1-2: 25-26.

Gullan P.J. \& CRanston P.S. 1998: The Insects: An Outline of Entomology. Chapman \& Hall, London, 504 pp.

HANSEN L.S. \& JENSEN K.M.V. 1996: Upper lethal temperature limits of the common furniture beetle Anobium punctatum (Coleoptera: Anobiidae). - Int. Biodeter. Biodegr. 37: 225-232.

Henderson P.A. 2003: Practical Methods in Ecology. Blackwell Oxford, $163 \mathrm{pp}$.

Huang L., Chen B. \& Kang L. 2007: Impact of mild temperature hardening on thermotolerance, fecundity and HSP gene expression in Liriomyza huidobrensis. - J. Insect Physiol. 53: 1199-1205.

Jurc M., Bojović S., Komjanc B. \& KRČ J. 2009: Xylophagous entomofauna in branches of oaks (Quercus spp.) and its significance for oak health in the Karst region of Slovenia. Biologia 64: 130-138.

KeENA M.A. 2006: Effects of temperature on Anoplophora glabripennis (Coleoptera: Cerambycidae) adult survival, reproduction and egg hatch. - Environ. Entomol. 35: 912-921.

KeEna M.A. \& Moore P.M. 2010: Effects of temperature on Anoplophora glabripennis (Coleoptera: Cerambycidae) larvae and pupae. - Environ. Entomol. 34: 1323-1335.

Lombardero M.J. \& Fernández de Ana Magán F.J. 1996: Distribución y daños de Coroebus florentinus (Herbst) (Col., Buprestidae) en Galicia (NO de la Península Ibérica). Ecología 10: 499-508.

LURIE S. \& JANG E.B. 2007: The influence of heat shock proteins in insect pests and fruits in thermal treatments. In Tang J., Mitcham E., Wang S. \& Lurie S. (eds): Heat Treatments for Postharvest Pest Control. CABI International, Wallingford, pp. 269-290.

Malagón J., Garrido A. \& Del Busto T. 1988: Oviposición de Capnodis tenebrionis L. (Col.: Buprestidae) en ambiente controlado. - Bol. San. Veg. Plagas 14: 99-105.
Margaix C. \& Garrido A. 2000: Efecto de temperaturas constantes en el desarrollo de Phyllocnistis citrella Stainton (Lepidoptera: Gracillariidae). - Bol. San. Veg. Plagas 26: 277-283.

McMillan D.M., Fearnley S.L., Rank N.E. \& Dahlhoff E.P. 2005: Natural temperature variation affects larval survival, development and HSP70 expression in a leaf beetle. - Funct. Ecol. 19: 844-852.

Mironidis G.K. \& Savopoulou-Soultani M. 2010: Effects of heat shock on survival and reproduction of Helicoverpa armigera (Lepidoptera: Noctuidae) adults. $-J$. Therm. Biol. 35: 59-69.

Montoya J.M. 1988: Los Alcornocales. Ministerio de Agricultura, Pesca y Alimentación, Madrid, 267 pp.

Mushrow L., Morrison A., Sweeney J. \& Quiring D. 2004: Heat as a phytosanitary treatment for the brown spruce longhorn beetle. - The Forestry Chronicle 80: 224-228.

Myers S.W., Fraser I. \& Mastro V.C. 2009: Evaluation of heat treatment schedules for emerald ash borer (Coleoptera: Buprestidae). - J. Econ. Entomol. 102: 2048-2055.

Neargarder G., Dahlhoff E.P. \& Rank N.E. 2003: Variation in thermal tolerance is linked to phosphoglucose isomerase genotype in a montane leaf beetle. - Funct. Ecol. 17: 213-221.

Nzokou P., Tourtellot S. \& Kamden D.P. 2008: Kiln and microwave heat treatment of logs infested by the emerald ash borer (Agrilus planipennis Fairmaire) (Coleoptera: Buprestidae). - For. Prod. J. 58: 68-72.

OstafF D.P. \& Cесн M.Y. 1978: Heat Sterilization of Sprucepine-fir Lumber Containing Sawyer Beetle Larvae (Coleoptera: Cerambycidae) Monochamus sp. Rept. OP-X-200E. Eastern Forest Products Lab., Ottawa, 9 pp.

OstafF D.P. \& Shields J.K. 1978: Reduction of Losses to Logs and Lumber Caused by Wood Boring Insects. Rept. OP-X218E. Eastern Forest Products Lab., Ottawa, Ontario, 15 pp.

Plieninger T., Pulido F.J. \& Konold W. 2003: Effects of land-use history on size structure of holm oak stands in Spanish dehesas: implications for conservation and restoration. - Environ. Conserv. 30: 61-70.

Rivas J. 2000: Daños causados en encinar por Coraebus florentinus (Col. Buprestidae) e incidencia de sus enemigos naturales en la finca "Las Navas". Proyecto Fin de Carrera, E.T.S.I.A.M, Universidad de Córdoba, 72 pp.

Rodrigo R. \& Herranz J.L. 2006: Actas de Reunión del Acuerdo de Encomienda de Gestión entre la Administración General del Estado, Ministerio de Medio Ambiente (Dirección General para la Biodiversidad-DGB) y el Consejo Superior de Investigaciones Cientificas (CSIC) para el control biorracional de plagas del Género Coraebus. Ministerio de Medio Ambiente y Medio Rural y Marino, Madrid, 15 pp.

Romanyk N. \& CAdahia D. 1992: Plagas de Insectos en las Masas Forestales Españolas. 2nd ed. Ministerio de Agricultura, Pesca y Alimentación, ICONA, Colección técnica, Madrid, $272 \mathrm{pp}$.

Roonwal M.L. 1971: Heat tolerance of larvae and adults of ghoon beetle Dinoderes ocellaris (Coleoptera: Bostrychidae). - J. Indian Acad. Wood Sci. 2: 55-62.

SCHAEFER L. 1949: Les Buprestides de France. Le Moult, Paris, $511 \mathrm{pp}$.

Scott M., Berrigan D. \& Hoffmann A.A. 1997: Cost and benefits of acclimation to elevated temperature in Trichogramma carverae. - Entomol. Exp. Appl. 85: 211-219.

Simpson W.T. 2001: Heating Times for Round and Rectangular Cross Sections of Wood in Steam. General technical report FPL-GTR-130, Department of Agriculture, Forest Service, Madison, 103 pp. 
SlanSKY F. \& SCRIBER J.M. 1985: Food consumption and utilization. In Kerkut G.A. \& Gilbert L.I. (eds): Comprehensive Insect Physiology, Biochemistry and Pharmacology. Vol. 4. Pergamon, Oxford, pp. 87-163.

SмITH R.S. 1991: The Use of Heat Treatment in the Eradication of the Pinewood Nematode and its Vectors in Softwood Lumber. Report to the Task Force on Pasteurization of Softwood Lumber, Forintek Canada Corporation, Vancouver, 72 pp.

Snyder T.E. \& St. George R.A. 1924: Determination of temperature fatal to the powder post beetle, Lyctus planicollis LeConte, steaming infested ash and oak lumber in a kiln. $-J$. Agric. Res. 28: 1033-1038.

Sobek S., Rajamohan A., Dillon D., Cumming R.C. \& Sinclair B.J. 2011: High temperature tolerance and thermal plasticity in emerald ash borer Agrilus planipennis. - Agric. Forest Entomol. 13: 333-340.

Solinas M. 1974: Coroebus florentinus (Herbst) (Coleoptera, Buprestidae). Biologia, danni, lotta. - Entomologica 10: 141-193.

SORIA F.J. 1990: Estudios biológicos sobre Coroebus undatus (Fabricius) y Coroebus florentinus (Herbst) (Coleoptera, Buprestidae) en alcornocales de Andalucía Occidental. $\mathrm{PhD}$ Thesis, Universidad de Sevilla, $326 \mathrm{pp}$.

SoRIA F.J. \& OCETE M. 1993: Estudios poblacionales sobre Coroebus florentinus (Herbst) (Col., Buprestidae) en alcornocales andaluces. [Population studies on Coroebus florentinus (Herbst) (Col., Buprestidae) in Andalusian cork-oak forests.] - Bol. San. Veg. Plagas 19: 27-35.

Soria F.J., Villagrán M. \& CÁRdEnAS A.M. 1996: Distribución e incidencia de los principales perforadores de la encina en el
Parque Natural de las Sierras Subbéticas (Córdoba, España). -Zool. Baetica 7: 33-43.

SPSS Inc. 2011: SPSS 20.0 for Windows Use Manual (version 20.0).

SteHR F.W. 1983: Immature Insects. Vol. 2. Kendall Hunt, Dubuque, $974 \mathrm{pp}$.

Thomas D.B. \& Shellie K.C. 2000: Heating rate and induced thermotolerance in Mexican fruit fly (Diptera: Tephritidae) larvae, a quarantine pest of citrus and mangoes. - J. Econ. Entomol. 93: 1373-1379.

Tomminen J. \& Nuorteva M. 1992: Pinewood nematode, Bursaphelenchus xylophilus in commercial sawn wood and its control by kiln-heating. Scand. J. For. Res. 7: 113-120.

Verdugo A. 2005: Fauna de Bupréstidos de la Península Ibérica y Baleares. Arganda, Barcelona, $350 \mathrm{pp}$.

WINERITER S.A. \& WALKER T.J. 1984: Insect marking techniques: durability of materials. - Entomol. News 95: $117-123$.

ZAR J.H. 1984: Biostatistical Analysis. Prentice Hall, New Jersey, $663 \mathrm{pp}$.

Zhou X., Perry J.N., Woiwod I.P., Harrington R., Bale J.S. \& CLARK S.J. 1997: Temperature change and complex dynamics. - Oecologia 112: 543-550.

Zocchi R. 1953: Una eccezionale infestazione di Coroebus fasciatus Villiers in Toscana. - Redia 38: 163-168.

http://www.juntadeandalucia.es/agriculturaypesca/ifapa. Estaciones Agroclimáticas. Instituto de Investigación y Formación Agraria y Pesquera, Consejería de Agricultura y Pesca, Junta de Andalucía. Accessed April, 2012.

Received May 18, 2012; revised and accepted August 17, 2012

Appendix 1. Average temperature $\left({ }^{\circ} \mathrm{C}\right) \pm$ Standard Deviation (SD) at the different locations in the tree from which the branches were collected. The results of the U-Mann Whitney (Z), Kruskal-Wallis (H) statistical tests of the differences in the temperatures recorded in different positions in the canopies of the trees. $\mathrm{P}$ - probability for $\alpha=0.05 . \mathrm{N}=160$ recordings for each location. Asterisk $(*)$ indicates significant values.

\begin{tabular}{|c|c|c|c|}
\hline \multirow{2}{*}{\multicolumn{2}{|c|}{ Average temperature $\left({ }^{\circ} \mathrm{C}\right) \pm \mathrm{SD}$}} & \multicolumn{2}{|c|}{ U Mann Whitney values } \\
\hline & & \multirow{2}{*}{$\frac{\mathrm{Z}}{-2.01}$} & \multirow{2}{*}{$\begin{array}{c}\mathrm{P} \\
0.04^{*}\end{array}$} \\
\hline Upper canopy & $\begin{array}{l}\text { North: } 29.30 \pm 7.14 \\
\text { South: } 30.56 \pm 8.05\end{array}$ & & \\
\hline Lower canopy & $\begin{array}{l}\text { North: } 28.04 \pm 6.54 \\
\text { South: } 30.23 \pm 8.07\end{array}$ & -4.79 & $0^{*}$ \\
\hline Both positions & $\begin{array}{l}\text { North: } 28.66 \pm 6.87 \\
\text { South: } 30.39 \pm 8.05\end{array}$ & -4.51 & $0^{*}$ \\
\hline North side & $\begin{array}{l}\text { Upper half: } 29.30 \pm 7.14 \\
\text { Lower half: } 28.04 \pm 6.54\end{array}$ & -1.75 & 0.08 \\
\hline South side & $\begin{array}{l}\text { Upper half: } 30.56 \pm 8.05 \\
\text { Lower half: } 30.23 \pm 8.07\end{array}$ & -0.19 & 0.85 \\
\hline Both orientations & $\begin{array}{l}\text { Upper half: } 29.93 \pm 7.63 \\
\text { Lower half: } 29.13 \pm 7.42\end{array}$ & -1.32 & 0.19 \\
\hline \multirow{2}{*}{\multicolumn{2}{|c|}{ Average temperature $\left({ }^{\circ} \mathrm{C}\right) \pm \mathrm{SD}$}} & \multicolumn{2}{|c|}{ Kruskal-Wallis values } \\
\hline & & $\mathrm{H}$ & $\mathrm{P}$ \\
\hline $\begin{array}{l}\text { North side upper canopy: } 29.30 \pm 7.14 \\
\text { South side upper canopy: } 30.56 \pm 8.05\end{array}$ & $\begin{array}{l}\text { North side lower canopy: } 28.04 \pm 6.54 \\
\text { South side lower canopy: } 30.23 \pm 8.07\end{array}$ & 24.36 & $0^{*}$ \\
\hline
\end{tabular}

